\title{
HVORFOR ER KRIMINALITET EN SOSIAL REALITET?
}

\section{Av førsteamanuensis LeIf Petter OlaUsSEN}

In 1987, Nils Christie argued that "crime does not exist" - a belief he has repeated in later publications. In this article, it is argued that crime is an agreement expressing collective intentionality. As such, the social existence of crime cannot be doubted. Crime is called an agreement because it is rooted in general agreement on (i) basic moral issues connected to evil acts; (ii) the need to have social institutions to protect citizens from specific evil acts; and (iii) a list of acts that citizens should be protected from and that perpetrators may be punished for.

These agreements are based on the fact that human beings are communicative actors, socially connected to each other, with a capacity and need to solve common problems produced by acts challenging peaceful social life where people respect each other's integrity and property. The category of crime is obviously socially constructed in a very specific sense: Although it is based on firm moral agreements, it is created by citizens who have developed a collective intentionality, a 'we', who consciously agree on (ii) and (iii) above therefore create social institutions (through legitimate social procedures) empowered to act in accordance with these agreements. The social reality of crime is constituted by the institutionalisation of these agreements, i.e. the empowerment of certain people with means, rights and obligations to protect and punish citizens. Accordingly, crime is not a collection (or list) of certain acts, and exists as a social fact as long as the institutionalisation is maintained.

\section{Innledning}

For sytten år siden skrev Nils Christie at: "Kriminalitet finnes ikke. Bare handlinger som innen forskjellige rammer gis forskjellig mening" (1987, s. 297). Og videre: "Først er det straff. Deretter blir den begåtte handling kriminalitet" (s. 298). Dette har han gjentatt i flere senere arbeider (Christie 2004). Synspunktet medfører at kriminalitet framstår som en slags sum av enkelthandlinger som har blitt kriminalitet fordi noen (i strafferettssystemet) har tildelt dem denne meningen. Etter min oppfatning er påstanden at kriminalitet ikke finnes, like urimelig og uholdbar som Thomas Aquinas' påstand at fattigdom ikke finnes, bare rikdom.

\footnotetext{
* Title in English: Why is Crime a Social Fact? Original in Norwegian.
} 
(Etter hans oppfatning kunne Gud bare være ansvarlig for det som finnes). At det er mulig å spore en vestlig metafysisk tradisjon helt tilbake til Platon (se Sjaastad, 1993, s. 110-111) der det onde (i meget vid forstand: kulde er fravær av varme, mørke er fravær av lys osv.) frakjennes en selvstendig eksistens, $\varnothing$ ker etter mitt syn ikke troverdighet av Christies påstand, men gir den en idéhistorisk klangbunn.

Jeg vil argumentere for en annen forståelse av kriminalitet, blant annet med forankring i sentral, klassisk sosiologi. Denne forståelsen innbærer at kriminalitet både er handlinger med en bestemt kvalitet, og at kriminalitet er en sosial realitet som finnes uavhengig av enkelthandlinger. Med utgangspunkt i Max Webers sosiologi vil jeg betegne kriminalitet (i sist nevnte forstand) som en enighetskategori. Som dette er den et viktig handlingsvilkår for oss alle, ved at den henviser til høyst reelle vurderings- og tenkemåter om handlinger, fordi de er forpliktende og konsekvensrike som følge av at de har allmenn sosial gyldighet. De vurderings- og tenkemåter som enighetskategorien kriminalitet viser til, kan også betegnes som sosiale fakta i Durkheims forstand, fordi de representerer en sosial tvang:

"A social fact is to be recognized by the power of external coercion which it exercises or is capable of exercising over individuals, and the presence of this power may be recognized in its turn either by the existence of some specific sanction or by the resistance offered against every individual effort that tends to violate it" (1968, s. 10).

Og jeg er enig med Durkheim i at det ikke er mulig å tvile på deres eksistens:

"We cannot doubt their existence, (...) Not only are they within us, but as they are a product of repeated experiences, they derive from repetition and from the habit resulting from it, a sort of dominance and authority. We feel their resistance when we try to shake them off. We are bound to confer the character of reality on phenomena which oppose us" (1968, s. 18).

Og sosiale fakta er som ting (Durkheim 1968, s. 14 og 27), i den forstand at den enkelte ikke kan modifisere dem ved viljens hjelp. Det er snarere slik at de sosiale fakta former våre viljer. De er som "støpeformer" som våre handlinger uunngåelig blir preget av, viste han til. Uunngåelig - fordi vi er henvist til å leve i fellesskap med andre.

\section{Innvevd, forent $\mathrm{og}$ forbundet (om typer av enighet)}

Max Weber vektla at mennesker er reflekterende og handlende. Som handlende er vi reflekterende vesener, begge deler som følge av vår medfødte evne til å beherske språk, til å foreta moralske-/verdibaserte vurderinger og til å handle for- 
målsrasjonelt. Dette er en del av vår "basisutrustning" som gjør oss til moralske vesener og setter oss i stand til å skape ulike relativt varige sosiale ordninger basert på både implisitt og eksplisitt enighet.

Selv om både uenighet og konflikt er normale sosiale fenomener, inngår ulike typer av enighet som en meget sentral forutsetning for en lang rekke fenomener som kjennetegner det menneskelige fellesskap. Dette er en følge av at vi er det Jürgen Habermas kaller kommunikative vesener, som er i stand til å samle og drøfte erfaringer, og som ofte søker å finne løsninger på problemer, også når disse er felles for mange. Dette perspektivet er av sentral betydning for å forstå at kriminalitet er noe annet og mer enn en sum av enkelthandlinger, som (mer eller mindre tilfeldig ?) blir betegnet som kriminalitet.

Når vi handler sosialt, vil både våre handlinger og vår måte å forstå egne og andres handlinger på, være preget av at vi ikke er alene (slik Robinson Crusoe var), men lever i samliv med andre mennesker. Samlivet med hverandre betyr, slik jeg tolker Weber (1999, s. 56-90), at vi er:

- $\quad$ innvevd med hverandre

- forent med hverandre

- forbundet med hverandre [i "naturlige" fellesskap - Gemeinschaft] [f.eks. i interessefellesskap - Gesellschaft] [ved felles institusjoner-Gesellschaft]

Selv om begrepet Gemeinschaft ofte viser til samliv preget av "nære" og tette sosiale relasjoner mellom mennesker, henviser det også til mer enn dette. Derfor har jeg valgt begrepet innvevd. Gemeinschaft viser også til at vi lever i store, omfattende fellesskap som karakteriseres ved felles språk, fellesskap i moralske oppfatninger, og bruk av felles byttemidler (markedsfellesskap). De samfunn som mennesker fødes inn i, preges blant annet av å være slike fellesskap. I disse fellesskapsrelasjonene, Gemeinschaft, som jeg foreslår å kalle innveving, er enigheten om hva som gjelder, ikke eksplisitt avtalt: Man har ikke avtalt med hverandre hva ord skal bety, og hvilke regler språket skal følge, og man har heller ikke (alltid) avtalt hva som er gyldige byttemidler, eller hvor grensene mellom god og dårlig moral går. Men til tross for at det ikke foreligger noen avtale om dette, har språket, byttemidlene og moralen sosial gyldighet (om man vil bli forstått, om man vil ha den varen man ønsker, og om man vil unngå misbilligelse). De handlinger som preges av at den handlende er innvevd i et fellesskap (språk, moral, marked) karakteriserer Weber som enighetshandlinger, fordi handlingen er utført under en forutsetning om bred enighet om hvilke regler som gjelder (for språk, moral, marked). Reglene på disse områdene har sosial gyldighet, som om de hadde vært avtalt, selv om man ikke føler seg forpliktet slik man ville gjøre når det foreligger en uttrykkelig avtale, mente Weber.

Den andre hovedtypen av fellesskap, Gesellschaft, er knyttet til relativt varige sosiale ordninger, som i stor grad har sitt grunnlag i våre evner og vilje til å 
søke enighet med andre for å oppnå noe i fellesskap. Disse ordningene oppleves som forpliktende av den enkelte og består for det første av ulike ordninger som mennesker har en eller annen bevisst hensikt med å etablere, på grunnlag av eksplisitt enighet om et formål. De er basert på formålsenighet, og når de er etablert, forholder mennesker seg til dem fordi de føler seg (mer eller mindre) forpliktet til det på grunnlag av enigheten. Et typeeksempel på slike ordninger er ulike interessebaserte ordninger. De dannes av, og forener, mennesker som mener at de på en eller annen måte har felles interesser (i f. eks. fagforeninger, arbeidsgiverforeningen). Slike ordninger forener og forplikter også de som melder seg inn lenge etter at ordningen ble etablert. Aktiv innmelding på grunnlag av interessefellesskap, er typisk for relasjoner som karakteriseres som forening, og innmeldingen forplikter den enkelte på ulikt vis.

Men vi er også forpliktet gjennom sosiale ordninger som ikke er basert på aktiv innmelding eller oppslutning om et avgrenset formål. Typeeksempelet er ordninger som utgjør den politiske enhet som kalles en stat. Vi får medlemskap i en stat ved fødsel, eller etter å ha bodd der en bestemt tid. Og Weber viser til at mennesker som lever sammen i slike politiske fellesskap er forbundet med hverandre gjennom de institusjoner som er etablert som del av et politisk-, sosialt- og kulturelt fellesskap (utdanningssystem, forsvar, domstoler, politi, politiske institusjoner osv.). Når vi samhandler, påpeker Weber, vil vi orientere våre handlinger ut fra at slike institusjoner finnes. Det vil si at vi legger til grunn, tar for gitt, at de institusjonaliserte ordningene har sosial gyldighet, at de er legitime. Slik samhandling kaller han forbundshandlinger, som altså er basert på legitimitetsenighet (enighet om legitimitetsgunnlaget).

Kriminalitet forstått som sosial realitet, som enighetskategori, er etter min oppfatning, forankret $\mathrm{i}$ at vi både er innvevd og forbundet med hverandre i et sosialt fellesskap, der enighet er av helt fundamental betydning, både for hvordan vi handler, for hvordan vi vurderer handlinger og hvordan vi forholder oss til ulike handlinger. De vurderings- og tenkemåter som den kognitive kategorien kriminalitet hviler på og derfor henviser til, er for det første uttrykk for allmenn enighet om viktige moralsk-/etiske spørsmål som ligger til grunn for og regulerer de nære og tette sosiale relasjoner mellom mennesker, i Gemeinschaft. Og for det annet er de uttrykk for vår forankring i Gesellschaft, dvs. i allmenn enighet om hvordan vi legitimt som medlemmer i et bestemt samfunn, bør og skal forholde oss til bestemte typer av handlinger. Om vi sier om en handling (X) at den er kriminalitet, henger vi ikke bare et ord eller en "merkelapp" på den. Og vi gjør mer enn blott og bart å anvende en sosiokulturell kategori (slik Høigård 1997 mener). Vi gir uttrykk for at det er bred sosial enighet om hvordan handlingen vurderes moralsk, og om hvordan folk i dette samfunnet legitimt bør og skal forholde seg til handlinger av denne typen. Den som bruker kategorien kriminalitet 
(f. eks. ved å anmelde en handling) påberoper seg følgelig allmenn sosial gyldighet for sin vurdering av handlingen, i lys av allmenne moralske oppfatninger (som er kjent ved innveving med andre) og i lys av legitime institusjonelle ordninger (som forbinder alle) i samfunnet. - Og strafferettsprosessen er en prosess som blant annet er instituert for å bekrefte eller avkrefte hvor vidt en slik vurdering virkelig hadde allmenn sosial gyldighet i det samfunnet der den ble framsatt, f. eks. ved at en handling ble anmeldt.

\section{Allmennmoral og kriminalitet}

Også Emil Durkheim var opptatt av å få fram at det sosiale fellesskapet som mennesker er innvevd i, blant annet er et moralsk fellesskap, og at det er bred (men ikke unison) enighet om sentrale moralske oppfatninger. Det er slånde at Durkheims påpeking av forbindelsen mellom kriminalitet og felles moralske oppfatninger, ikke synes å ha noen relevans for Christie (1987) og Høigård (1997) for å forstå hva kriminalitet er.

Det essensielle hos Durkheim er hans påpeking av at kriminalitet er like handlinger - $i$ den forstand at alle samfunnsmedlemmer vanligvis misbilliger dem (1933, s.73). Og i likhet med Weber var han opptatt av å få fram den moralske enigheten, og at forbrytelser krenker kollektive følelser. Og siden disse følelsene

"finnes i alle bevisstheter, vekker forgåelsen indignasjon i alle de som har bevis for den eller som får kjennskap til den. Alle er angrepet; følgelig vil alle motsette seg angrepet. Reaksjonen er ikke bare generell, men den er kollektiv, som ikke er det samme. Den skapes ikke isolert i hver enkelt, men med totalitet og i enhet, (...) Kriminalitet bringer sammen rettskafne bevisstheter og konsentrerer dem. (...) De kreftene det dreier seg om, får sin kraft fra det faktum at de er felles for alle. De er sterke fordi de er uomtvistet. Det som høyner den særmerkte respekt som de er gjenstand for, er at de er universelt respektert. (...) Kriminaliteten skader således denne enstemmigheten som er kilden til deres autoritet" (1933, s. 102, min oversettelse).

Videre påpekte han (op.cit.) at det at vi misbilliger slike handlinger, er dypt inngravert i alle (op.cit. s.74), slik at straffelovgivningen bare endres svært langsomt (op.cit. s.78).

Det Durkheim kalte for kollektiv bevissthet eller følelser i sitatet ovenfor kan i stor grad byttes ut med begrepet allmennmoral, slik dette brukes av filosofen Knut Erik Tranøy (2001). Han viser til at menneskets evner til å tenke og felle moralske dommer tilhører menneskets konstitutive evner, i like stor grad som evnen til å lære språk. Og alle språk har et moralsk begrepsrepertoar der svært mye er felles: 
"begreper for rett og galt, godt og ondt, løgn og sannferdighet, og for dyder og laster som mot, rettferdighet og måtehold, grådighet, feighet og gjerrighet - ord som tross alle oversettelsesproblemer lar seg oversette fra ett språk til alle andre fordi de har de samme eller tilsvarende begreper" (Tranøy 2001, s. 166).

Og fordi disse begrepene er en del av alle språk, kan mennesker ikke unngå å lære allmennmoralen som råder grunnen i den kulturen hver enkelt av oss blir født inn i og er innvevd i. Språklæring og moraltilegning vil gå hånd i hånd $\mathrm{og}$ gjøre oss til mennesker, med menneskeverd og verdighet. Og språket og allmennmoralen er forutsetninger for at vi kan utvikle en selvbevissthet som menneske, som også har relasjoner til andre mennesker.

Tranøy understreker (op.cit. s. 41) at det ikke er mulig å unngå å være moralsk i den forstand at vi må eller vil foreta vurderinger med utgangspunkt i fortellinger om godt og ondt, rett og galt, og det finnes ingen posisjon utenfor allmennmoralen, skriver han. Med begrepet allmennmoral mener han alminnelige menneskers moral, og den

"består av det sett av moralske verdier, normer og dyder - og de tilsvarende praksiser og institusjoner - som har bred aksept og er internalisert og respektert i en gitt kultur til en viss tid." (op.cit. s. 106-107 ${ }^{1}$ )"Allmennmoralen er i bunn og grunn et sosialt system, et delsystem av det altomfattende sosiale system vi kaller en kultur" (op.cit. s. 181).

Påstanden om at det finnes en allmennmoral betyr imidlertid ikke at Tranøy mener at det finnes én moral som alle slutter opp om, eller at det ikke finnes moralske kontroverser og viktig uenighet om moralske spørsmål. Tvert imot, og slik forstår jeg både Weber og Durkheim. Et trekk ved allmennmoralen (i Vesten) er at den

"er pluralistisk i den mening at den rommer og kan være virkefelt for både fornuft, følelser, interesser, behov og åpenbaringer etc., uten nødvendigvis å opphøye en bestemt av disse til en priviligert posisjon og funksjon, (...) Et av de mest karakteristiske trekk ved allmennmoralen er interaksjonen mellom dens forskjellige prinsipper - dens verdier, normer og dyder - ..." (op.cit. s. 121).

Videre skriver han:

"Til de vestlige allmennmoraler hører ikke bare de verdier, normer og dyder som har bred aksept og er internalisert av de mange. Vel så viktig i dette

\footnotetext{
${ }^{1}$ Se også nyanseringen s. $158 \mathrm{i}$ hans bok.
} 
perspektiv er det jeg prøver å uttrykke med ordene "som er respektert [...] i en gitt kultur". Denne respekten skal manifestere seg først og fremst i viljen og evnen til å leve med at det er lov å ha andre moralske overbevisninger enn dem jeg har. Dette er et vesentlig trekk i det vi kaller åndsfrihet (...) Det er også dette som reflekteres i metaforen det åpne sinn. Vi kunne kalle det Voltaires prinsipp" (op.cit. s. 129-130).

Til tross for at det finnes flere allmennmoraler mener Tran $\varnothing \mathrm{y}$ at det analytisk kan skilles mellom to nivåer i det allmennmoralske systemet: et grunnivå og et høyere nivå. Grunnivået (eller allmennmoralens "grunnmur") er forholdsvis stabilt og varig, er preget av betydelig tverrkulturell enighet, gir forholdsvis lite rom for personlig moral (på dette nivået) og består i hans typologi av tre typer elementer:

- Grunnleggende begreper med tilknytning til det moralske liv

- Bio-moralske verdier:

o Verdier som liv og overlevelse slik at slekten kan fortsette, omsorg for avkom, og et minimum av livskvalitet

○ Rett til et minimum av trygghet

- Moralske forbud mot drap, tyveri og løgn

- Viktige substansielle moralske normer som:

- Løfter og avtaler skal holdes

- Respekt for andre meninger enn dine egne

- Onder av alle slag $b \varnothing r$ forhindres og unngås når det lar seg gjøre; onde handlinger må derfor være forbudte

Allmennmoralens høyere nivå er mindre stabilt, mer preget av "forgjengelighet", er mindre preget av tverrkulturell enighet og gir større rom for personlige valg og preferanser, for personlig moral. Moral med tilknytning til ekteskap, samlivsformer, prevensjon, abort, religion, og andre familieforhold kan tjene som eksempler, også på at moralske oppfatninger på dette nivået kan gjennomgå relativt store endringer i løpet av ganske korte tidsrom.

Av stor betydning for hva kriminalitet er, bør det minnes om at moralen er medmenneskeorientert, orientert mot hvordan vi kan opptre overfor andre. Moralske spørsmål handler om hvilke hensyn mennesker bør eller skal ta til hverandre (og til dyr, planter og livsmiljøet forøvrig) når vi forfølger våre mål og interesser, påpeker Tranøy (op.cit. s. 48). Det samme gjelder de vurderinger som 
medfører at bestemte handlinger regnes som kriminalitet. Og Tranøy har rett i at det er bred enighet om at:

"Krenkelse av de bio-moralsk verdier er blant de juridisk og moralsk alvorligste forbrytelser i vår kultur, selv om de bio-moralske verdiene ikke på noen måte er tilstrekkelige for utviklingen av en fullstendig moral for mennesker. Slike forbrytelser berører så åpenbart noe som kan kalles en felles grunn. Men det er også opplagt at disse "moralsk primitive" verdier henger sammen med noen av de dypeste menneskelige behov, drifter og begjær - og i de alvorligste frustrasjoner og lidelser som menneskelivet rommer. Derfor er behovet for og retten til et minstemål av trygghet også et aspekt av den felles grunn som defineres av de bio-moralske verdiene" (op.cit. s. 30).

Én viktig forbindelse moral og kriminalitet (som legitim, institusjonalisert tenkeog vurderingsmåte) er at begge er knyttet til handlinger. I den vestlige kultur er det et grunnleggende skille mellom på den ene siden ikke-moralske onder (naturlig forårsakete jordskjelv, snøskred, vulkanutbrudd, sykdom, dødsfall), og på den annen side moralske onder. Og Tranøy minner om at:

"den viktigste forskjellen mellom moralsk og ikke-moralsk godhet og ondskap er forankret i menneskelige intensjoner i forbindelse med handlinger som berører andres velferd" (op.cit. s.97). Og: "Den verste type ond og ondsinnet handling, både juridisk og moralsk, er bevisst, omhyggelig planlagt og uten formildende omstendigheter å påføre uskyldige mennesker lidelser og skade fordi den som gjør det, selv har glede av det"( op.cit. s.91).

Og Tranøy fremhever at det

"faktum at barn i sin sosiale praksis legger vekt på å skille mellom å skade noe eller en annen med vilje (med overlegg eller forsett), og å skade en annen ved et uhell styrker antakelsen om at denne distinksjonen tilhører de grunnleggende elementer i (Vestens) allmennmoral" (op.cit. s. 93).

Dermed kommer forbindelsen mellom moralske vurderinger av onde handlinger og strafferettslig tenking om skyld til syne ved at

"et eller annet kriterium på ansvarlighet eller tilregnelighet [må] være oppfylt før man kan kjenne en person moralsk eller juridisk skyldig i en umoralsk eller straffbar handling" (op.cit. s. 92).

Og det er straffeloven som har overtatt sondringene fra allmennmoralen, ikke omvendt, mener Tranøy. Og det gir seg nesten selv at det er en sterk indre sammenheng mellom på den ene side strafferettens vilkår for skyld, og på den annen 
side de moralske vilkår for skyld, som Tranøy beskriver slik, der (i) er den verste kategorien av handling:

"Vilkår for moralsk skyld: overlegg, forsett og uaktsomhet.

(i) Skade forvoldt ved handling som er utført med overlegg (som er planlagt) i den hensikt å fremkalle en bestemt skade.

(ii) Skade forvoldt ved handling som er villet, men ikke overlagt (ikke på forhånd planlagt) - som er gjort med forsett.

(iii) Skade forvoldt ved handling som er utført uten overlegg eller forsett, men ved uaktsomhet.

(iv) Skade forvoldt ved handling som er verken overlagt eller forsettlig og heller ikke uaktsom, men hvor handlingens skadevirkning skyldes et hendelig uhell" (op.cit. s. 89).

Tranøy presiserer naturligvis at handlinger innen kategori (iv) verken er moralsk klanderverdige eller kan medføre skyld i strafferettslig forstand, fordi den handlendes hensikt, intensjon eller tanke har vært en helt annen enn skadeforvoldelse.

Det kan etter mitt syn ikke være tvil om at handlingskategorien kriminalitet viser hen til og bygger på allmenn enighet om moralske spørsmål av den typen som her er tatt opp: retten til liv, et minimum av livskvalitet og trygghet, moralske forbud mot drap, tyveri, løgn, og at onder av alle slag, inklusive onde handlinger, bør forhindres og unngås og må være moralsk forbudte. Denne enigheten som ikke er oppstått ved avtale mellom menneskene, er vi alle innvevd i, og den er en meget viktig forutsetning for og element i den kollektive intensjonalitet som har skapt og opprettholder kriminalitet som sosialt faktum.

\section{Kriminalitetens tre-enige institusjonelle grunnlag}

Både vår samtid og $\mathrm{i}$ meget fjern og nær fortid er menneskenes historie full av eksempler både på menneskers gode og onde handlinger mot hverandre. De onde er blant annet representert ved drap og andre fysisk angrep på hverandre, at noen tar ting som andre mener de har rett til å beholde for seg selv, at sterke (f. eks. menn) går løs på eller utnytter svake (f. eks. kvinner og barn) som ikke kan forsvare seg. Allmenn menneskelig erfaring tilsier at det alltid har vært, er og vil være en viss risiko for slike overgrep og problemer av ulikt slag der mennesker lever sammen. Gjennom ulike praksiser har mennesker, fordi vi er kommunikative vesener, drøftet og bearbeidet både sine erfaringer med slike handlinger, og med ulike måter de har forsøkt å forholde seg til dem på. De mange og ulike strafferettsteoriene og lovene er produkter av og ledd i denne kommunikative, problemløsende virksomheten.

Erfaringer og diskusjoner av slike felles problemer over lang tid utgjør etter min oppfatning det sosiokulturelle fundamentet for etablering av viktige institu- 
sjonelle ordninger som handlingskategorien kriminalitet viser til og er forankret i. De institusjonelle ordningene er skapt for å løse høyst reelle sosiale behov for å håndtere en rekke mellommenneskelige problemer som moralsk uakseptable handlinger av nevnte type til enhver tid har skapt. Gjennom normativ argumentasjon, prøving og feiling, er det skapt allmenn enighet blant samfunnsmedlemmene om at først og fremst mennesker og viktig virksomhet skal beskyttes mot bestemte handlinger, og at de som ikke etterlever denne enigheten skal kunne straffes for enighetsstridige handlinger. Som en manifestasjon av denne enigheten - om både å beskytte og å kunne straffe de som opptrer enighetsstridig - er det også bred enighet om at det er nødvendig å opprette og opprettholde en særlig tvangsmakt som har til formål å realisere enigheten om å beskytte og kunne straffe.

Enigheten betyr at et hvert samfunnsmedlem som mener seg utsatt for bestemte handlinger, har legitim rett til å henvende seg til dette maktorganet og be om beskyttelse hvis det er nødvendig, og kreve at gjerningspersonen blir straffet, hvis det er $\emptyset$ nskelig og mulig. Dessuten er det bred normativ enighet om at det bør være slik, hvis samfunnet skal kunne håndtere bestemte problemer, beskytte svake parter, og samtidig kunne fungere som et samfunn, som "et rimelig system for samarbeid over tid fra en generasjon til neste, der de som er med i samarbeidet ses på som frie og likeverdige borgere og normalt samarbeidende medlemmer av samfunnet gjennom et helt liv" (Rawls 2003, s. 54). At handlinger som tyveri og drap og andre former for fysiske angrep og aggresjon, voldtekt og incest blir negativt sanksjonert universelt kommer av at slike handlinger er grunnleggende uforenlig med et samfunn som er "velordnet", "et rimelig system for samarbeid", og der partene er "frie og likeverdige", og handlingene er i strid med grunnleggende allmennmoralske prinsipper.

Dannelsen av enighetsbaserte institusjoner som sanksjonerer slike enighetsstridige handlinger på vegne av samfunnsmedlemmene, begynte i høymiddelalderen i Europa, på 11-1200-tallet i Norge (Helle 1974, s. 186ff). Grunnlaget for denne tidfestingen er at det som kalles landefredslovgivningen begynte å gjøre seg gjeldende fra Magnus Erlingsons tid (1161-1184), og den ble initiert av både kirken og kongen. ${ }^{2}$ Det representerte noe nytt at kongen, en sentral fellesmakt, kunne skape ny rett fordi retten ble ansett som tradisjonelt bestemt, overlevert sedvane, ikke som noe som kunne skapes av en lovgiver. Landefredslovgivningen avspeiler at kirken og (den gryende) statsmakt forsøkte å etablere sosiale institusjoner som hadde legitimitet til å håndtere konflikter, slik at rimelig grad av fred og orden kunne råde. På den ene siden ble det innført bestemmelser som medførte sterk økning i antallet úbotemál (handlinger som

\footnotetext{
${ }^{2}$ Allerede på slutten av høymiddelalderen hadde kongen nokså velutdannede rådgivere rundt seg (Helle 1974, s. 214, 135 og 265)
} 
gjorde så ubotelig skade at erstatningsoppgjør mellom partene var utelukket): ulike typer av vold, kvinnerov og røveri (ran). Den som begikk slike handlinger kunne drepes straffritt (med mindre kongen hadde "fredet" ham), og det ble úbotemál å kreve hevn eller bot for forøveren, som hadde "forbrudt alt sitt gods". Slike bestemmelser ble innført til skrekk og advarsel, og til fordel for en slunken statskasse. På den annen side forsøkte kirken og kongen å stimulere til inngåelse av fredelige forlik. De fikk tingfolket til å godkjenne bestemmelser om at retten til privat blodhevn skulle begrenses. Grunnen var at den tradisjonelt aksepterte blodhevnen og erstatningsoppgjør, som bare kunne sikres ved trussel om hevn hvis den avtalte erstatningen ikke ble betalt, kunne føre til omfattende ufred (ættefeider) over lange tidsrom. Dertil ble det innført lovbestemmelser som hadde til hensikt å tvinge folk til å akseptere det vi ville kalle erstatningsoppgjør, i større grad enn tidligere. Det ble en plikt å fors $ø$ ke å bli enige om et erstatningsoppgjør ved en lang rekke handlinger som vi i dag ville kalle kriminalitet. - Men hva skulle skje dersom denne plikten ble forsømt, eller den omforente erstatningen ikke ble betalt? Dette problemet kunne bare løses på fredelig vis ved at kongemakten fikk folkelig godkjenning som legitim håndhevingsmyndighet, selvsagt mot betaling. ${ }^{3}$ Fra nå av etableres det gradvis i Norge felles maktorganer til håndtering av visse mellommenneskelige konflikter, og fundamentet for senere institutionelle ordninger som kategorien kriminalitet viser, til gror fram.

Men opprettelse av maktorgan med slike oppgaver, kan selvsagt skape nye problemer som kan bli meget følbare, og mye historisk erfaring har da også vist at maktorganer kan komme til å gå ut over de fullmakter de var gitt. Diskusjoner av slike problemer (gjennom lang tid) har skapt utbredt forståelse for og enighet om at alle maktinstanser må temmes, holdes i tøyler, for å unngå at de går ut over sine fullmakter og gjør noe ganske annet enn det som var formålet med opprettelsen av dem.

Etter min oppfatning er straffelovgivningen et svært sentralt element i det ordnede rettsamfunnets virkemidler for å temme makten, skapt på bakgrunn av innsikt i den betydning dette har. Denne lovgivningen (pluss en del andre lover) er et svært viktig virkemiddel til å avgrense den makt politi og det øvrige rettssystem skal ha til å gripe inn overfor mennesker og virksomhet. Derfor er legalitetsprinsippet så viktig i strafferetten. Ved at de straffbare handlinger skal være uttømmende beskrevet, er det satt grenser for maktorganets adgang til å begrense vår frihet som samfunnsmedlemmer, til å handle uten å kunne bli stanset og straffet.

Straffeloven er dermed ikke bare en lov om straff. Den er i minst like høy grad en meget sentral sikring av frihet, og til å beskytte personer og virksomhet. Jeg ser det følgelig ikke slik at juristene har stjålet konfliktene fra folk. De har

\footnotetext{
${ }^{3}$ En offentlig bot, sekten, og sakefallet, se Helle 1974, s. 187 og 195.
} 
heller bidratt til å trekke grenser som sikrer frihet til å leve i fred og til å utføre lovlig virksomhet, og til å sikre at vi alle har rett og mulighet (men ingen generell plikt) til å rapportere overgrep som rammer oss - og be om beskyttelse mot slike handlinger. De konflikter folk melder til politiet, uten å ha noen plikt til det, er angrep og overgrep de ikke vil finne seg i, og hvor de mener det er legitimt og fordelaktig å koble inn et maktorgan med høy legitimitet. Ved anmeldelse til politiet kan anmelderen få bekreftet at den anmeldte handlingen er kollektivt for$d ø m t$, og ikke bare personlig brysom eller ubehagelig. Dette er nok ofte like vesentlig som å oppnå materielle goder (erstatning), uten å måtte å bruk egen tid eller egne penger på å forfølge saken selv. Derfor finner man intet folkelig opprør med krav om å få konfliktene tilbake fra politi og strafferettssystem, men snarere en offentlighet der ingen sak er for bagatellmessig til å bli anmeldt, nulltoleranse. $\mathrm{Vi}$ anmelder stort og smått fordi dette er vår eneste mulighet til å fortelle at vi utsettes for handlinger som vi selv mener er kollektivt fordømt, og til å få dette bekreftet.

Kategorien kriminalitet viser etter mitt syn til det sosiale faktum at det er meget bred enighet $\mathrm{i}$ vårt samfunn om tre viktige forhold som henger tett sammen med hverandre:

- Det finnes - og bør finnes - et samfunnsmessig maktapparat som enhver borger kan påkalle når han/hun mener seg utsatt for uakseptable handlinger eller overgrep.

- Maktapparatet skal selv avgjøre hvor vidt det er grunn til å gripe inn, og i tilfelle hvordan det skal gjøres. Men maktapparatet er også forpliktet til å rettferdiggjøre (legitimere) sin handlemåte (inngripen eller ikke), ikke bare overfor de umiddelbart impliserte, men overfor hele samfunnet.

- Dette er mulig, fordi det også er bred enighet om hvilke handlinger som skal gi grunnlag for maktapparatets inngripen, og hvordan dette kan skje, slik at det kan fastslås når maktapparatet har legitim adgang til å gripe inn, og hvilke midler det legitimt kan benytte.

Denne enigheten kommer til uttrykk i en kollektiv intensjonalitet, en kollektiv vilje til å institusjonalisere denne treenigheten, som samlet konstituerer det legitime institusjonelle fundamentet for enighetskategorien kriminalitet.

Siden kategorien kriminalitet på nevnte måte er knyttet til en sosial institusjonell orden som er opprettet ved enighetsbaserte beslutninger (legitimert ved at bestemte prosedyrer er fulgt), kan man med referanse til den amerikanske filosofen John Searl (1995) betegne kriminaliteten som en sosial konstruksjon, i 
meget spesifikk forstand: Den er et institusjonelt faktum. Det som er felles for slike institusjonelle sosiale fakta er at de oppstår som folge av at mennesker blir enige om à tillegge et objekt eller en person en spesiell status og en tilhørende funksjon. Det vil si at de blir enige om at: "X skal telle som $Y i C$ ", (sett inn $\mathrm{f}$. eks. $\mathrm{X}=$ med hensikt å skade en annen person; $\mathrm{Y}=$ kriminalitet; $\mathrm{C}=$ Norge.). $\mathrm{Og}$ enigheten som skaper institusjonelle fakta, dreier seg alltid om plassering av makt eller plikt til å gjøre noe. Det særegne ved slike fenomener, påpeker Hacking (2000, s. 22), er at de er ontologisk subjektive og epistemologisk objektive. At de er ontologisk subjektive vil si at de er skapt og opprettholdes av enighet mellom mennesker som (subjektivt) ønsker og mener at fenomenene skal finnes (at "X skal telle som Y i C"), og institusjonaliserer enigheten. Men slik kollektiv intensjonaliet kan naturligvis opphøre, og da vil også det institusjonaliserte sosiale faktum opphøre, dvs. at "X ikke lenger teller som Y i C". Det forhold at de institusjonelle faktas varen er enighetsbetinget, og betinget av språk og prosedyrer for institusjonalisering av enigheten, medfører naturligvis $i k k e$ at disse fakta er epistemologisk subjektive, slik at enhver som har lyst til det, bare kan erklære dem som ikke-eksisterende. De er i høyeste grad epistemologisk objektive, det vil si fenomener som har en realitet uavhengig av hva en enkeltperson måtte mene om dets eksistens, nettopp fordi erklæringen om at "X skal telle som Y i C" medfører at noen har fått makt og plikt (på vegne av fellesskapet) til å sørge for at erklaringen blir reell. Og det vil være en realitet inntil det kollektivt besluttes noe annet. Det er dette som ligger i at enigheten er institusjonalisert. Penger og lån i banken er hverdagslige eksempler på at sosiale fakta både er ontologisk subjektive og epistemologisk objektive: avhengige av bestemte sosiale ordninger som er institusjonalisert av mennesker, og at det ikke nytter for den enkelte (låntaker) å benekte deres (bankens, pengenes, lånets) eksistens.

Siden institusjonelle fakta har sitt grunnlag i institusjonalisert sosial enighet, vil man ikke kunne få tak på hva kriminalitet $e r$ ved å studere enkelthandlinger, slik Christie (1987) og Høigård (1997) synes å mene. Kriminalitet er ikke en samling av handlinger, heller ikke den som er spesifisert i straffeloven, men den institusjonaliserte enighet loven manifesterer. Straffeloven (og noen andre lover) beskriver handlinger som er det Searl (1995, s. 35) generelt kaller "brute facts": manifestasjoner av den enighet som er institusjonalisert, og som kan observeres i form av merker på papir, som lyder som kommer ut av folks munn, og til og med som tanker i folks hode. Siden vi er innvevd, forent og forbundet med hverandre i et sosialt fellesskap, er vi alle fortrolige ikke bare med den moralske enighet, men også med den institusjonaliserte enighet som konstituerer kriminaliteten. Derfor "vet" alle hva kriminalitet er, selv uten noen gang å ha lest i straffeloven.

${ }^{4}$ Collin (1997, s. 194 ff) benytter betegnelsen konvensjonelle fakta i nokså sammenfallende betydning. 
Og vi innretter oss alle deretter, inklusive tyven, skriver Weber (1999, s. 50). Tyven orienterer sine handlinger etter straffelovens gyldighet ved å forsøke å skjule sin handling. Det at han skjuler den, viser at han handler sosialt, selv om ingen andre enn tyven er til stede når handlingen blir utført. På denne måten minner en av sosiologiens klassikere oss om at kriminaliteten finnes som sosial realitet lenge før en handling blir utført, og at kriminaliteten blant annet manifesterer seg som tanker seg $\mathrm{i}$ våre hoder, som leder til at vi forsøker å skjule visse handlinger eller lar være å utføre dem.

\section{Konklusjon}

Kategorien kriminalitet finnes i alle samfunn som har institusjonalisert et maktapparat på bakgrunn av kollektiv enighet om at dette skal håndtere nærmere avgrensede former for onde handlinger som med hensikt eller uaktsomhet påfører andre skade. Men dette betyr ikke at maktapparatet frembringer eller skaper de uønskete handlingene. Ord som kriminalitet, forbrytelse eller forseelse formidler den moralske og institusjonaliserte enighet. De er lesbare og hørbare manifestasjoner av enigheten.

En påstand om at kriminalitet finnes som sosial realitet betyr at en alminnelig enighet om følgende punkter, er institusjonalisert:

- Vi bør og skal ha legitim rett til beskyttelse mot visse onde handlinger av et samfunnsmessig maktorgan.

- Maktorganet må ha rett til å gripe inn, også på eget initiativ $i$ visse sammenhenger, og om nødvendig straffe den som med hensikt/uaktsomt har påfort andre skade ved slike handlinger.

- De handlinger som gir maktorganet rett til å gripe inn og straffe, må vare avgrenset gjennom sosiale prosesser som sikrer utbredt enighet om hvilke handlinger det skal kunne gripe inn overfor, og med hvilke midler.

Det er denne institusjonaliserte enighet eller kollektive intensjonalitet som gjør det berettiget å hevde at kriminalitet finnes som sosialt faktum. Og fordi den er institusjonalisert, rokkes den ikke av meningsutsagn fra enkeltpersoner. Institusjonaliserte sosiale realiteter kan bare skapes, opprettholdes og avskaffes gjennom kollektive prosedyrer. Men det kan man bare få øye på om man vektlegger at vi er reflekterende og handlende vesener som er innvevd, forent og forbundet med hverandre i et sosialt fellesskap, der vi på grunnlag av kollektiv enighet kan bestemme hva som skal gjelde som sosiale realiteter. 


\section{Litteratur}

Christie, N. (1987):'Fagets fiender". Nordisk Tidsskrift for Kriminalvidenskab, s. 291-299.

Christie, N. (2004): En passende mengde kriminalitet. Universitetsforlaget, Oslo.

Collin, F. (1997): Social Reality. Routledge, New York.

Durkheim, E. (1933): The Division of Labor in Society. The Free Press/Macmillan Publishing Co, New York.

Durkheim, E. (1968): The Rules of Sociological Method. The Free Press/Collier-MacMillan, New York/London.

Hacking, I. (2000): Social Construction of What? Harvard University Press, Cambridge.

Helle, K. (1974): Norge blir en stat 1130-1319. Universitetsforlaget, Oslo.

Høigård, C. (1997): "Hva er kriminologi?" Kap 1, s. 13-29, i: L. Finstad og C. Høigård (red.): Kriminologi. Pax forlag, Oslo.

Rawls, J. (2003): Rettferdighet som rimelighet. En reformulering. Pax forlag, Oslo 2003.

Searl, J.R. (1995): The Construction of Social Reality. The Free Press, New York/London. Sjaastad, Ø.(1993): "Gottfried Wilhelm Leibniz", s. 94-117 i: T. Berg Eriksen (red.): Vestens Tenkere, bd 2, Acshehoug, Oslo.

Tranøy, K. E. (2001): Det åpne sinn. Moral og etikk mot et nytt årtusen. 2. utg.

Universitetsforlaget, Oslo.

Weber, M (1999): Verdi og handling. Pax forlag, Oslo.

Adresse:

Institutt for kriminologi og rettssosiologi

Juridisk fakultet

$\mathrm{Pb} .6706$, St. Olavs plass

N-0130 Oslo

E-post: 1.p.olaussen@jus.uio.no 